\title{
NEW VISION OF THE CULTURE BY THE ART IN THE CONTEMPORARY PAINTING TO ACHIEVE SOCIAL RESPONSIBILITY
}

Ghadeer Muhammad Abboud AFIF *

Department of Painting and Arts, College of Design and Art, King Abdul-Aziz University, Saudi Arabia

\begin{abstract}
The study sheds light on new vision of the culture by the art in the Contemporary painting to achieve social responsibility. It focuses on origination new resources of the culture by the art in painting field which can take part in production of contemporary works to achieve social responsibility. The study's issue summarizes a probability of the culture by the art in contemporary painting to achieve social responsibility. This study aims to affirm the importance of the culture by the art and the activation of its role in contemporary painting for achieving social responsibility. Moreover, it aims to originate resources of the culture by the art which fit all artworks and enriches the art field in general and painting in particular. The research also follows the descriptive analytical approach. The most significant result shows that an origination resource of the culture by the art achieves social reasonability. The benefit of the culture by the art concept contributes in contemporary painting works production that can enrich the visual culture and artistic experience of the cultured by the art. The researcher recommended the importance of the culture by the art and activation its role as social responsibility in contemporary painting. On the other side, the researcher appeals the necessary of studying cultivation concept in artists' works in art field in general and painting in particular.

Keywords

Vision, The Culture, The Art, The Contemporary Painting, Social Responsibility.
\end{abstract}

\section{Introduction}

Art is considered a cognitive cultural means that has an effective role in society, and a language of communication through which the artist seeks to spread the culture represented in the values, trends, standards, beliefs or relationships that organize interaction between individuals with the aim of serving society. Art education is a process that aims to promote culture through art and the artist's production of contemporary artworks with multiple directions, dealing with some Concepts from different angles for the purpose of raising awareness, receiving knowledge and gaining new experiences for specific groups of society. Where it is determined Trends in art education include customs, traditions, beauty, and others, and it follows that he is a socially and professionally responsible artist morally and legally. And make him aware of the consequences of his behavior in society.

A new vision of art education will be discussed in contemporary photography to achieve social responsibility through the following axes: The first axis: the concept of education and its objectives.

The second axis: the concept of social responsibility, its importance and elements. The third

* Corresponding author: ghadeer.afif@ hotmail.com 
axis: art education as a responsibility social in contemporary photography.

\section{Research Problem:}

Can art education in contemporary photography achieve social responsibility?

\section{Research Hypotheses :}

Types of art education in contemporary photography can be created that achieve social responsibility.

\section{Research Aims:}

1. Emphasizing the importance of art education and activating its role in contemporary photography to achieve social responsibility.

2. Creating art education types that are suitable for all artistic works and enrich the field of art in general and photography in particular.

\section{Research Importance:}

-Giving attention to the concept of art education and making use of it in the production of contemporary graphic works that enrich visual culture and experience artistic.

- The importance of creating types of art education that is compatible with artistic works that contribute to achieving social responsibility.

\section{Research limits:}

The research is limited to art education for professionals and non- specialists in the field of art, and it deals with the works of contemporary artists) in $21^{\text {st }}$ century (Educated through art).

\section{Research Methodology:}

The research follows the descriptive and analytical approach.

The first axis: the concept of art education: The concept of art education is divided into two different parts represented by the meaning of art and culture, which are two sides of one thing, so there is no art that can be fully understood without culture, nor a culture far from art. The concept of art education is based on cultural revitalization as one of the most basic functions of plastic art in general, so spreading culture is an approach related to employing art in the service of environment and society.

Art is considered a human educational and gastronomic activity, and it is a communication language that has its own vocabulary. The artists differed and differed views and critics about his concept. He defined art as a human activity represented in the individual communicating his emotions to others.

Art was also known as an attempt to innovate to create interesting shapes, and these shapes saturate our sense of beauty in an unconventional way, by producing works it includes sensory, imaginary, emotional and symbolic elements that impose their presence on the recipient's 
senses "and increase the desire for contemplation. And its repetition more than once (Attia $2112 \mathrm{AD}, 11)$. Art is a human phenomenon that is symbolically represented by forms that reflect the artist's culture. And the culture of the society in which he lives.

Culture in its broadest sense refers to the way of life of society in all its aspects, which is represented in values, trends and standards methods of thinking, beliefs, or relationships that regulate interaction between community members (Mahmoud 2119 AD, 11).

It is the environment that man creates through the influence of his work in the outside world, and it includes tools, machines, and works of art tools of thought, words, concepts, mental techniques, arithmetic, and skills.

\section{Results:}

The creation of art education in contemporary photography achieves social responsibility. Utilizing the concept of art education that contributes to the production of contemporary photographic works that enrich visual culture and artistic expertise have the literate.

The creation of art education types suitable for all artistic works enriches the field of art in general and photography in general especially.

\section{Recommendations:}

The researcher recommends emphasizing the importance of art education and activating its role as a social responsibility in contemporary photography.

* The need to pay attention to studying the concept of education in the works of artists in the field of art in general and photography in particular.

\section{Conclusion}

The research dealt with a new vision for art education in contemporary photography to achieve social responsibility through the creation types of photography education that contribute to the production of contemporary works that enrich visual culture and artistic expertise. And make an artist

A socially responsible person who serves through his art the individual and society. The research idea revolves around the following axes:

The first axis: the concept of education and it includes the concept of culture, its divisions, and its association with art.

The second axis: the concept of social responsibility and includes its definition, forms, importance, elements and pillars.

The third axis: art education as a social responsibility in contemporary photography and includes the development of types of education art, and deals with the works of contemporary 
artists who have been educated in art.

\section{Reference}

1) Ibrahim, Magdy Aziz (2119 A.D.) Dictionary of Terms and Concepts of Teaching and Learning, Cairo: The World of Books.

2) Ibrahim, Anees and others (2113): The Wasit Dictionary, Part 1, Beirut: Dar Al-Waves.

3) El-Gohary, Abdel-Hadi (2111) Studies in Political Science and Political Sociology, Alexandria: University Library Al-Harithi, Zayed Ajeer (4115 AD) Personal social responsibility of a sample of Saudi youth in the Western Region and its relationship to some variables, Educational Research Center, Qatar University, Issue 09) (, C5.

4) Al-Shal, Mahmoud Al-Nabawi (1911 A.D.) Contemporary Plastic Arts, Al-Tarabiah newspaper: Al-Gabalawi Press.

5) Al-Sayrafi, Muhammad (2119) Social Responsibility for Administration, 1st floor, Alexandria: Dar Al-Wafa for the World of Printing and Publishing.

6) Al-Omari, Mona Saad Faleh (2119 AD) The cognitive method (deliberation / impulsion) and its relationship to social responsibility among a sample of female students of the College of Education for Girls in Jeddah Governorate, a master's thesis, College of Education, Taibah University, Madinah

7) Al-Mahdi, Ahmad Muhammad (4195 CE): The Relationship between Participation and Social Responsibility among High School Students, Unpublished Master Thesis, College of Education, Ain Shams University.

8) Besar, Muhammad (1993), Belief and Morals, Beirut: Lebanese Book House.

9) Hegazy, Muhammad Zaki Al-Din (4191 A.D.): Responsibility in Islam, ed., Jeddah: Saudi Publishing and Distribution House.

10) Hanin, Evan Adib Kamel (2111 AD), Multimedia as an Introduction to Contemporary Advertising Design in the Field of Art Education, Master Thesis, Faculty of Art Education, Helwan University, Cairo.

11) Hanin, Ihab Adib Kamel (2112 AD) Building a proposed educational strategy to evaluate the performance of the intellectual in art according to learning trends in the twentyfirst century, Ph.D., Faculty of Art Education, Helwan University, Cairo.

12) Rafiqa, Senegra (2113 A.D.) The impact of applying social responsibility on the performance of human resources in small enterprises

13) And Intermediate, Master Thesis, Faculty of Economics, Business and Management Sciences, Qasdi Merbah University, Algeria.

14) Reed, Herbert (1991) The Meaning of Art, translated by Sami Khashaba: The Egyptian 
General Book Authority.

15) Zahran, Hamed (0222 AD): Social Psychology, Cairo: The World of Books.

16) Othman, Syed Ahmed (1992 AD) The Ethical Analysis of the Muslim Personality, Cairo: The Anglo-Egyptian Library.

17) Attia, Mohsen Muhammad (2112 A.D.) Discovering beauty in art and nature: the world of books

18) Issa, Maghawri Abd al-Hamid (4191 CE): The Need for Belonging, the Need for Achievement, and Their Relation to Social Responsibility, unpublished PhD thesis, College of Education, Suez Canal University

19) Qasim, Jamil Muhammad (2111 AD), the effectiveness of a mentorship program for the development of social responsibility among secondary school students, an MA thesis, College of Education, Islamic University, Gaza

20) Layla, Ali (2112 A.D.) Social Theory and Society Issues - Modernization and Sustainable Development Issues, Cairo: The Anglo-Egyptian Library.

21) Mahmoud, Mohamed Hamed (2119 AD), Multimedia Sculpture as an Introduction to Artistic Practices in the Field of Art Education, Master Thesis, Faculty of Art Education, Helwan University, Cairo.

22) Murad, Abdel Fattah, Encyclopedia of Scientific Research and the number of letters, research and literature, Egypt.

23) Musharraf, Maysoon Muhammad Abdul Qadir (2119 AD) Moral thinking and its relationship to social responsibility and some variables among students of the Islamic University of Gaza, Master Thesis, College of Education, Islamic University, Gaza.

24) Maalouf, Lewis (1993) Al-Munajjid fi linguistics and flags, Beirut: Dar Al-Mashriq.

25) Beck, Mitchell, A.(1997) Managing the unmanageable student, A choice theory ,reality therapy ,approach to understanding behavior, International, Journal, of Reality, therapy Fal

26) Brown, Francis J (1955) Education Sociology, New York : Prentice Hall INC.

27) Eliot, T.S (1964) Intelligent Reading England, London : Langemens, Green,comp.

28) Fairchild, Henry Pratt and others (1964): dictionary of sociology Paterson

29) Hendreson, J . Irvine (1981) The Concept of Responsibility and it`s place in moral

30) education, Florida : University Microfilms International.

31) Lindgreen, Adam and Swaen Valerie (2010) Corporte Social Responsibility, British:

32) Black Well.

33) Muller, D . J (1969) Differences in Social Responsibility among various group of collage students, Diss. Abs, Vol. 31. 
34) Nammour,Cesar (2008) Lotti Adaimi, Lobanon: Fine Arts Publishing.

35) Read, Herbert (2002) Art and Society, London : Routledge Classics.

36) Riggenbach, Heidi (2008) Perspedive on Fluency, Press : University of Michigan.

37) Noha Sayed Mohamed AFIFI, Arafa Shaker HASSAN, PRODUCTION AN EXTERNAL CLADDING UNITS USING RUBBER MOLD AND POLYESTER, International Journal of Multidisciplinary Studies in Art and Technology, Vol. 3, No. 1, 2020, pp. 1-6.

38) Hadeel Muhammad Aziz Nazmi SALEM, SPECIFIC SELECTIVE MEDIA INSPIRING IDEAS OF VISUAL EXPRESSION IN THE ARTISTIC SPACE: AN APPLIED STUDY IN THE FIELD OF PAINTING FOR THE INTERPHONE AND TRANSIENT EXHIBITION “THE MEDIUM SURVIVAL AND THE SURFACE IS A VISUAL PASSION", International Journal of Multidisciplinary Studies in Art and Technology, Vol. 3, No. 1, 2020, pp. 7-11.

Received: September 15, 2020

Accepted: November 20, 2020 